Short Communication

\title{
Kinetic inequivalence between $\alpha$ and $\beta$ subunits of ligand dissociation from ferrous nitrosylated human haptoglobin:hemoglobin complexes. A comparison with $\mathrm{O}_{2}$ and $\mathrm{CO}$ dissociation
}

\author{
Paolo Ascenzi ${ }^{\mathrm{a}, *}$, Giovanna De Simone ${ }^{\mathrm{b}}$, Andrea Pasquadibisceglie ${ }^{\mathrm{b}}$, Magda Gioia ${ }^{\mathrm{c}, \mathrm{d}}$, \\ Massimo Coletta ${ }^{\mathrm{c}, \mathrm{d}}$ \\ ${ }^{a}$ Interdepartmental Laboratory for Electron Microscopy, Roma Tre University, Via della Vasca Navale 79, I-00146 Roma, Italy \\ ${ }^{\mathrm{b}}$ Department of Sciences, Roma Tre University, Viale Guglielmo Marconi 79, I-00146 Roma, Italy \\ c Department of Clinical Sciences and Translational Medicine, University of Roma "Tor Vergata", Via Montpellier 1, I-00133 Roma, Italy \\ ${ }^{\mathrm{d}}$ Interuniversity Consortium for the Research on the Chemistry of Metals in Biological Systems, Via Celso Ulpiani 27, I-70126, Bari, Italy
}

\section{A R T I C L E I N F O}

\section{Keywords:}

Human haptoglobin 1-1:hemoglobin complex Human haptoglobin 2-2:hemoglobin complex Nitrogen Monoxide Dissociation

Kinetics

\begin{abstract}
A B S T R A C T
Haptoglobin (Hp) counterbalances the adverse effects of extra-erythrocytic hemoglobin (Hb) by trapping the $\alpha \beta$ dimers of $\mathrm{Hb}$ in the bloodstream. In turn, the $\mathrm{Hp}: \mathrm{Hb}$ complexes display Hb-like reactivity. Here, the kinetics of NO dissociation from ferrous nitrosylated $\mathrm{Hp}: \mathrm{Hb}$ complexes (i.e., $\mathrm{Hp} 1-1: \mathrm{Hb}(\mathrm{II})-\mathrm{NO}$ and $\mathrm{Hp} 2-2: \mathrm{Hb}(\mathrm{II})-\mathrm{NO}$, respectively) are reported at $\mathrm{pH} 7.0$ and $20.0^{\circ} \mathrm{C}$. NO dissociation from $\mathrm{Hp}: \mathrm{Hb}$ (II)-NO complexes has been followed by replacing NO with CO. Denitrosylation kinetics of Hp1-1:Hb(II)-NO and Hp2-2:Hb(II)-NO are biphasic, the relative amplitude of the fast and slow phase being $0.495 \pm 0.015$ and $0.485 \pm 0.025$, respectively. Values of $k_{\mathrm{off}(\mathrm{NO}) 1}$ and $k_{\mathrm{off}(\mathrm{NO}) 2}$ (i.e., $(6.4 \pm 0.8) \times 10^{-5} \mathrm{~s}^{-1}$ and $(3.6 \pm 0.6) \times 10^{-5} \mathrm{~s}^{-1}$ for Hp1-1:Hb(II)-NO and (5.8 \pm $0.8) \times 10^{-5} \mathrm{~s}^{-1}$ and $(3.1 \pm 0.6) \times 10^{-5} \mathrm{~s}^{-1}$ for $\left.\mathrm{Hp} 2-2: \mathrm{Hb}(\mathrm{II})-\mathrm{NO}\right)$ are unaffected by allosteric effectors and correspond to those reported for the $\alpha$ and $\beta$ subunits of tetrameric $\mathrm{Hb}(\mathrm{II})-\mathrm{NO}$ and isolated $\alpha$ (II)-NO and $\beta$ (II)-NO chains, respectively. This highlights the view that the conformation of the $\mathrm{Hb} \alpha_{1} \beta_{1}$ and $\alpha_{2} \beta_{2}$ dimers matches that of the $\mathrm{Hb}$ high affinity conformation. Moreover, the observed functional heterogeneity reflects the variation of energy barriers for the ligand detachment and exit pathway(s) associated to the different structural arrangement of the two subunits in the nitrosylated R-state. Noteworthy, the extent of the inequivalence of $\alpha$ and $\beta$ chains is closely similar for the $\mathrm{O}_{2}$, NO and $\mathrm{CO}$ dissociation in the R-state, suggesting that it is solely determined by the structural difference between the two subunits.
\end{abstract}

\section{Introduction}

Haptoglobin (Hp) is a chaperone-like molecule, which binds $\alpha \beta$ dimers of plasma $\mathrm{Hb}$, bringing about the formation of a very stable noncovalent complex, which prevents most harmful effects related to the presence of free $\mathrm{Hb}$ and/or free heme in the bloodstream, such as (i) heme dissociation from $\mathrm{Hb}$, and (ii) heme oxidation, facilitating the removal of $\mathrm{Hb}$ via the reticuloendothelial system and the CD163 receptor-mediated endocytosis by hepatocytes, Kupffer cells, and tissue macrophages [1-8]. Further, Hp binding to $\alpha \beta \mathrm{Hb}$ dimers prevents hydrogen-peroxide radical formation and migration, subunit dissociation, globin-cross linking, and heme release, thereby protecting the vascular system from damage by free $\mathrm{Hb}[8,9]$.

From a molecular viewpoint, $\alpha_{1} \beta_{1}$ (and $\alpha_{2} \beta_{2}$ ) dimers (i.e., the products of the tetramer to dimer dissociation of human hemoglobin; $\mathrm{Hb}$ ) have been always considered to be locked in the high-affinity $\mathrm{R}$ conformation (with no "heme-heme" interactions and no Bohr effect) [8,10-23]. Therefore, ligand binding properties of $\mathrm{Hb}$ dimers bound to haptoglobin (Hp) represent an excellent molecular model to study the functional features of pure dimeric species without the interference of

\footnotetext{
Abbreviations: BZF, bezafibrate; $\mathrm{Hb}$, human hemoglobin; $\mathrm{Hb}(\mathrm{III})$, ferric $\mathrm{Hb} ; \mathrm{Hb}(\mathrm{II})$, ferrous $\mathrm{Hb} ; \mathrm{Hb}(\mathrm{II})-\mathrm{O}_{2}$, oxygenated $\mathrm{Hb}(\mathrm{II}) ; \mathrm{Hb}(\mathrm{II})-\mathrm{CO}$, carbonylated $\mathrm{Hb}(\mathrm{II}) ; \mathrm{Hb}$ (II)-NO, nitrosylated $\mathrm{Hb}(\mathrm{II})$; Hp, human haptoglobin; Hp1-1, phenotype 1-1 of Hp; Hp1-1:Hb(III), ferric Hp1-1:Hb complex; Hp1-1:Hb(II), ferrous Hp1-1:Hb complex; Hp2-2, phenotype 2-2 of Hp; Hp2-2:Hb(III), ferric Hp 2-2:Hb complex; Hp2-2:Hb(II), ferrous Hp 2-2:Hb complex; IHP, D-myo-inositol 1,2,3,4,5,6hexakisphosphate; $\mathrm{Mb}$, myoglobin.

* Corresponding author.

E-mail address: ascenzi@uniroma3.it (P. Ascenzi).
} 


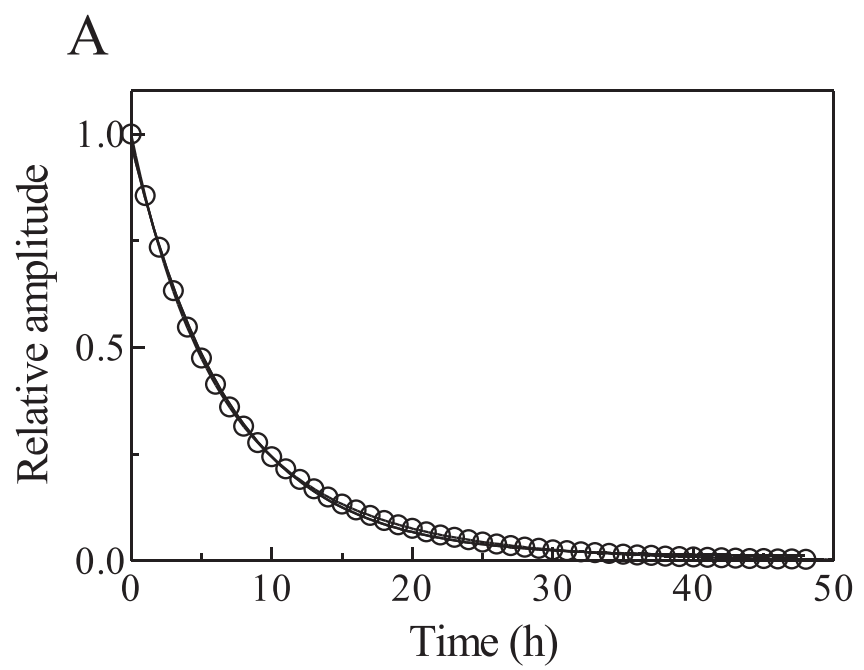

\section{B}
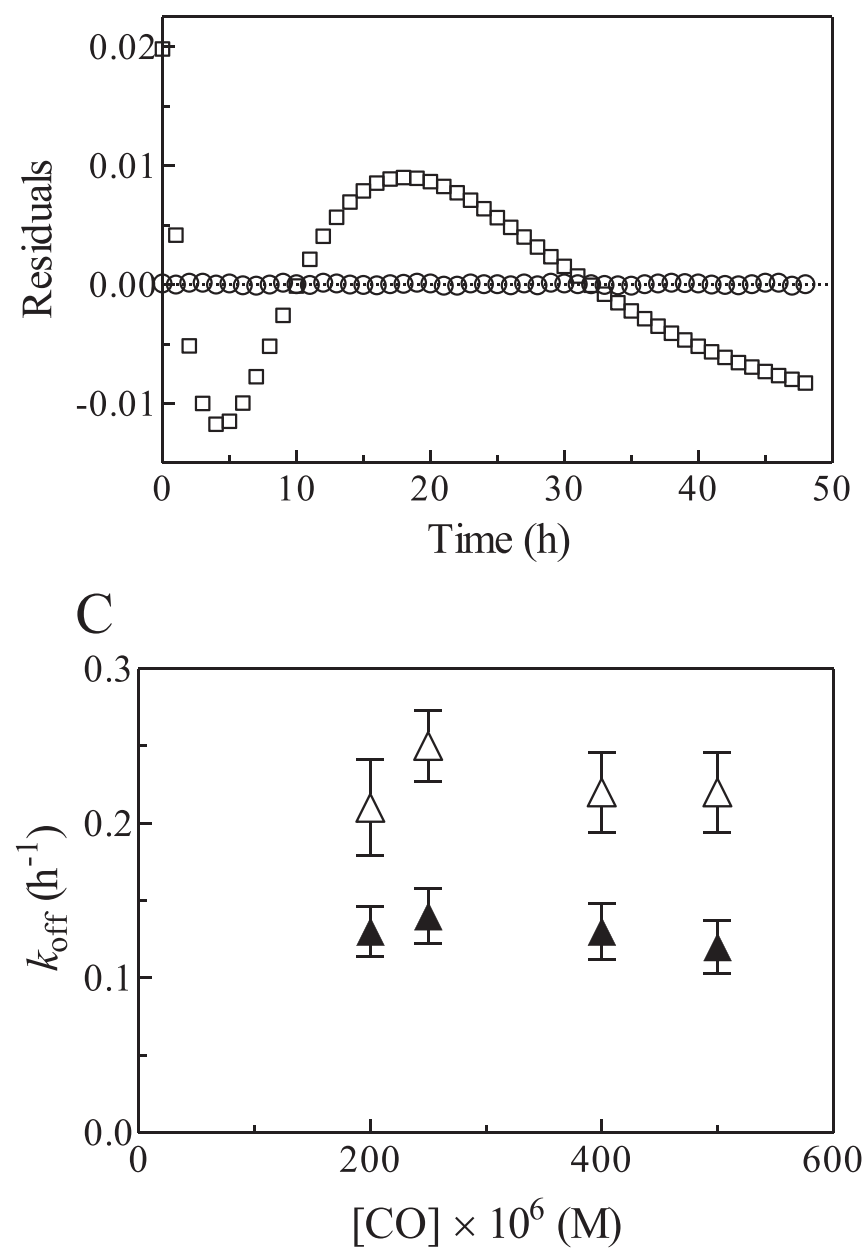

(caption on next column)
Fig. 1. Kinetics of NO dissociation from $\mathrm{Hp} 1-1: \mathrm{Hb}(\mathrm{II})-\mathrm{NO}$, at $\mathrm{pH} 7.0$ and $20.0{ }^{\circ} \mathrm{C}$. (A) Time course of NO dissociation from Hp1-1:Hb(II)-NO. The CO concentration was $5.0 \times 10^{-4} \mathrm{M}$. The time course analysis according to eq. (1) allowed to determine the values of $k_{\text {off(NO) } 1}=2.2 \times 10^{-1} \mathrm{~h}^{-1}\left(=6.1 \times 10^{-5}\right.$ $\left.\mathrm{s}^{-1}\right), A_{1}=0.48, k_{\text {off(NO) } 2}=1.2 \times 10^{-1} \mathrm{~h}^{-1}\left(=3.3 \times 10^{-5} \mathrm{~s}^{-1}\right)$, and $A_{2}=0.52$. The time course analysis according to eq. (2) allowed to determine the values of $k_{\text {off (NO) }}=1.4 \times 10^{-1} \mathrm{~h}^{-1}\left(=3.9 \times 10^{-5} \mathrm{~s}^{-1}\right)$ and $A=1.0$. (B) Residuals obtained from the non-linear least-squares fitting with one (squares; eq. (2)) and two (circles; eq. (1)) exponential(s) of data referring to NO dissociation from Hp1-1:Hb(II)-NO. (C) Dependence of the first order rate constant for NO dissociation from $\mathrm{Hp} 1-1: \mathrm{Hb}(\mathrm{II})-\mathrm{NO}$ on the $\mathrm{CO}$ concentration. The average values of $k_{\mathrm{off}(\mathrm{NO}) 1}$ and $k_{\mathrm{off(NO}) 2}$ are $2.3 \times 10^{-1} \mathrm{~h}^{-1}\left(=6.4 \times 10^{-5} \mathrm{~s}^{-1}\right)$ and $1.3 \times$ $10^{-1} \mathrm{~h}^{-1}\left(=3.6 \times 10^{-5} \mathrm{~s}^{-1}\right)$, respectively. The Hp1-1:Hb(II)-NO concentration was $4.8 \times 10^{-6} \mathrm{M}$. The dithionite concentration was $2.0 \times 10^{-3} \mathrm{M}$.

the tetrameric population, which is present to a relevant extent even at the lowest affordable concentrations (i.e., $5.0 \times 10^{-7}$ to $1.0 \times 10^{-6} \mathrm{M}$ ) in the in vitro experiments [24].

We have recently characterized the functional properties of ferrous and ferric $\mathrm{Hp}: \mathrm{Hb}$ complexes, putting in evidence a marked subunit functional heterogeneity for most of the ligands investigated (namely $\mathrm{O}_{2}$ and $\mathrm{CO}$ for the ferrous form and azide, thiocyanate and imidazole for the ferric form) $[8,23,25-27]$. However, only in the ferric form we have observed an assembly-linked structural change of ferric $\mathrm{Hb}$ upon dimer association to tetramer, as indicated by a much faster dissociation of the sixth axial ligand $\mathrm{H}_{2} \mathrm{O}$ from ferric hemes in $\mathrm{Hp}: \mathrm{Hb}$ complexes (as well as in isolated subunits) with respect to the tetramer [26,28].

Kinetics of the reductive nitrosylation of ferric human haptoglobin1-1: and haptoglobin2-2:hemoglobin complexes (Hp1-1: $\mathrm{Hb}(\mathrm{III})$ and $\mathrm{Hp} 2-2: \mathrm{Hb}(\mathrm{III})$, respectively) [21] allowed: (i) to estimate the values of the lowest limits of the second-order rate constant for Hp1-1: $\mathrm{Hb}(\mathrm{III})$ and $\mathrm{Hp} 2-2: \mathrm{Hb}(\mathrm{III})$ nitrosylation (i.e., $k_{\mathrm{on}} \geq 3.8 \times 10^{6} \mathrm{M}^{-1} \mathrm{~s}^{-1}$, since at the NO concentrations employed it was too fast to be observed by rapid-mixing stopped-flow technique) and of the first-order rate constant for $\mathrm{Hp} 1-1: \mathrm{Hb}(\mathrm{III})-\mathrm{NO}$ and $\mathrm{Hp} 2-2: \mathrm{Hb}(\mathrm{III})-\mathrm{NO}$ denitrosylation (i.e., $k_{\mathrm{off}} \geq 4.4 \times 10^{2} \mathrm{~s}^{-1}$ ), and (ii) to determine the values of the secondorder rate constant for the nitrosylation of ferrous human haptoglobin1-1: and haptoglobin2-2:hemoglobin complexes (Hp1-1: $\mathrm{Hb}(\mathrm{II})$ and $\mathrm{Hp} 2-2 \mathrm{Hb}(\mathrm{II})$; i.e., $1.1 \times 10^{7} \mathrm{M}^{-1} \mathrm{~s}^{-1}$ and $9.3 \times 10^{6} \mathrm{M}^{-1} \mathrm{~s}^{-1}$, respectively). Of note, kinetic parameters for (de)nitrosylation of $\mathrm{Hp}: \mathrm{Hb}$ (III)(-NO) and $\mathrm{Hp}: \mathrm{Hb}(\mathrm{II})(-\mathrm{NO})$ complexes agree with those reported for horse heart myoglobin (Mb), sperm whale $\mathrm{Mb}$, and human $\mathrm{Hb}$ [29-31].

Differently from $\mathrm{O}_{2}$ and $\mathrm{CO}$, values of the second-order rate constants for the nitrosylation of the $\mathrm{T}$ - and R-states $\mathrm{Hb}(\mathrm{II})$ are rather similar, indicating that the cooperativity for $\mathrm{NO}$ binding to $\mathrm{Hb}(\mathrm{II})$ is exclusively expressed on the ligand dissociation [15,30,32-34]. Therefore, only the determination of the NO dissociation rate constants allows a clear identification of the quaternary conformation of $\mathrm{Hp} 1-1: \mathrm{Hb}(\mathrm{II})-\mathrm{NO}$ and $\mathrm{Hp} 2-2: \mathrm{Hb}(\mathrm{II})-\mathrm{NO}$. Here, kinetics of NO dissociation from Hp1-1:Hb(II)$\mathrm{NO}$ and $\mathrm{Hp} 2-2: \mathrm{Hb}(\mathrm{II})-\mathrm{NO}$ by CO replacement are reported, highlighting the view that the conformation of the ferrous nitrosylated $\alpha \beta$ dimers bound to $\mathrm{Hp} 1-1$ and $\mathrm{Hp} 2-2$ matches that of the R-state of the $\mathrm{Hb}$ tetramer and of isolated $\alpha$ and $\beta$ subunits.

\section{Materials}

Human Hp1-1 and Hp2-2 were purchased from Athens Research \& Technology, Inc. (Athens, GA, USA) and Merck KGaA (Darmstadt, Germany). Oxygenated human $\mathrm{Hb}\left(\mathrm{Hb}(\mathrm{II})-\mathrm{O}_{2}\right)$ was prepared as previously reported [15]. The $\mathrm{Hp}: \mathrm{Hb}$ complexes were prepared by mixing $\mathrm{Hb}(\mathrm{II})-\mathrm{O}_{2}$ with $\mathrm{Hp} 1-1$ and $\mathrm{Hp} 2-2$ at pH 7.0 and $20.0^{\circ} \mathrm{C}[11,12,16,22]$. Each $\mathrm{Hp}$ dimer binds one or two $\alpha \beta$ dimers of $\mathrm{Hb}$. To avoid the occurrence of free $\mathrm{Hb}$ an excess of Hp1-1 and Hp2-2 (from 20 to 100\%) was present in all samples and the absence of free $\mathrm{Hb}$ was checked by gel electrophoresis (Fig. 1 SM of Supplementary Material) [12,35-37]. Hp1-1:Hb(II)-NO and $\mathrm{Hp} 2-2: \mathrm{Hb}$ (II)-NO (final concentration $4.8 \times 10^{-6} \mathrm{M}$ and $4.6 \times 10^{-6}$ 


$$
\mathrm{Hp}: \mathrm{Hb}(\mathrm{II})-\mathrm{NO}+\mathrm{CO} \underset{k_{\mathrm{on}(\mathrm{NO})}}{\rightleftarrows} \mathrm{kp}: \mathrm{Hb}(\mathrm{II})+\mathrm{NO}+\mathrm{CO} \underset{k_{\mathrm{off}(\mathrm{fO})}}{\stackrel{k_{\mathrm{on}}(\mathrm{CO})}{\rightleftarrows}} \mathrm{Hp}: \mathrm{Hb}(\mathrm{II})-\mathrm{CO}+\mathrm{NO}
$$

Scheme 1. Reaction mechanism of Hp1-1:Hb(II)-NO and Hp2-2:Hb(II)-NO conversion to $\mathrm{Hp}: \mathrm{Hb} 1-1(\mathrm{II})-\mathrm{CO}$ and $\mathrm{Hp} 2-2: \mathrm{Hb}(\mathrm{II})-\mathrm{CO}$, respectively.

$\mathrm{M}$, respectively) were prepared by adding dithionite (final concentration $2.0 \times 10^{-3} \mathrm{M}$ ) followed by the NO solution (final concentration $1.0 \times$ $10^{-5} \mathrm{M}$ ) to the deoxygenated $\mathrm{Hp} 1-1: \mathrm{Hb}(\mathrm{II})$ and $\mathrm{Hp} 2-2: \mathrm{Hb}(\mathrm{II})$ solutions [30].

NO and $\mathrm{CO}$ were purchased from Aldrich Chemical Co. (Milwaukee, WI, USA) and Linde AG (Höllriegelskreuth, Germany), respectively. NO was purified by passing it through a glass column packed with $\mathrm{NaOH}$ pellets followed by passing it through a trapping solution, which contained $20 \mathrm{~mL}$ of $5.0 \mathrm{M} \mathrm{NaOH}$, to remove traces impurities; the NO pressure was $760.0 \mathrm{mmHg}$ [38]. The $\mathrm{NO}$ and CO solutions in $5.0 \times 10^{-2}$ $\mathrm{M}$ phosphate buffer solution ( $\mathrm{pH}=7.2$ ) were prepared in a closed vessel under NO or $\mathrm{CO}$ at $P=760.0 \mathrm{mmHg}$ anaerobically at $20.0{ }^{\circ} \mathrm{C}$. The solubility of NO and $\mathrm{CO}$ in the aqueous buffered solution was $2.05 \times$ $10^{-3} \mathrm{M}$ and $1.03 \times 10^{-3} \mathrm{M}$, respectively, at $P=760.0 \mathrm{mmHg}$ and $20.0{ }^{\circ} \mathrm{C}$ [15]. All the other chemicals, including D-myo-inositol 1,2,3,4,5,6-hexakisphosphate (IHP) and bezafibrate (BZF), were purchased from Merck AG (Darmstadt, Germany). All chemicals were of analytical or reagent grade and were used without further purification unless stated.

\section{Methods}

The values of the first-order rate constant for NO dissociation from $\mathrm{Hp} 1-1: \mathrm{Hb}(\mathrm{II})-\mathrm{NO}$ and $\mathrm{Hp} 2-2: \mathrm{Hb}(\mathrm{II})-\mathrm{NO}$ (i.e., for NO replacement by CO; $\left.k_{\text {off(NO) }}\right)$ were determined by mixing the $\mathrm{Hp} 1-1: \mathrm{Hb}(\mathrm{II})-\mathrm{NO}$ and $\mathrm{Hp} 2-2$ : $\mathrm{Hb}(\mathrm{II})-\mathrm{NO}$ (final concentration, $4.8 \times 10^{-6} \mathrm{M}$ and $4.6 \times 10^{-6} \mathrm{M}$, respectively) solutions with the CO-dithionite solutions, in the absence and presence of IHP and BZF (final concentration, $2.0 \times 10^{-2} \mathrm{M}$ ), under anaerobic conditions, at pH $7.0\left(5.0 \times 10^{-2} \mathrm{M}\right.$ phosphate buffer $)$, and $20.0^{\circ} \mathrm{C}$; no gaseous phase was present [30]. Kinetics was carried out employing a SFM-20/MOS-200 rapid-mixing stopped-flow apparatus (BioLogic Science Instruments, Claix, France) and a Jasco V-650 spectrophotometer (Jasco, Tokyo, Japan), monitoring the progress curves at several single wavelengths spanning between 380 and $450 \mathrm{~nm}$. The conversion of $\mathrm{Hp} 1-1: \mathrm{Hb}(\mathrm{II})-\mathrm{NO}$ and $\mathrm{Hp} 2-2: \mathrm{Hb}(\mathrm{II})-\mathrm{NO}$ to $\mathrm{Hp} 1-1: \mathrm{Hb}(\mathrm{II})-$ $\mathrm{CO}$ and $\mathrm{Hp} 2-2: \mathrm{Hb}(\mathrm{II})-\mathrm{CO}$, respectively, was fitted to a two-exponential process according to the minimum reaction mechanism represented by Scheme 1 [30]. The final CO concentration ranged between $2.0 \times 10^{-4}$ $\mathrm{M}$ to $5.0 \times 10^{-4} \mathrm{M}$ and the final dithionite concentration was $2.0 \times 10^{-3}$ $\mathrm{M}$; the over 100-fold excess of CO over NO guarantees that the reaction proceeds rightward because $k_{\text {on }(\mathrm{CO})} \times[\mathrm{CO}]>>k_{\text {on }(\mathrm{NO})} \times[\mathrm{NO}]$ (see Scheme 1).

$$
k_{\text {off(NO) } \quad k_{\text {on }(\mathrm{CO})}}
$$

$\mathrm{Hp}: \mathrm{Hb}(\mathrm{II})-\mathrm{NO}+\mathrm{CO} \quad \mathrm{Hp}: \mathrm{Hb}(\mathrm{II})+\mathrm{NO}+\mathrm{CO} \quad \mathrm{Hp}: \mathrm{Hb}(\mathrm{II})-\mathrm{CO}+\mathrm{NO}$

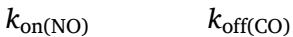

The values of $k_{\text {off(NO)1 }}$ and $k_{\text {off(NO)2 }}$ have been determined from data analysis, according to two-exponential eq. (1):

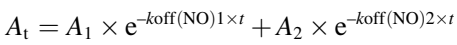

where $A_{\mathrm{t}}$ refers to the relative signal amplitude at a given time $=t$ for the reaction to be completed (i.e., [Hp:Hb(II)-NO $]_{\mathrm{t}} /[\mathrm{Hp}: \mathrm{Hb}(\mathrm{II})]_{\mathrm{tot}}$ ) and $A_{1}+A_{2}=1$ (i.e., $100 \%$ of the reaction) refers to the relative spectroscopic contribution of the two subunits, characterized by $k_{\mathrm{off}(\mathrm{NO}) 1}$ and $k_{\text {off(NO)2, }}$, respectively.

For comparison, kinetic data have also been analyzed according to the one-exponential eq. (2):

$A_{\mathrm{t}}=A \times \mathrm{e}^{-k \operatorname{off}(\mathrm{NO}) \times t}$

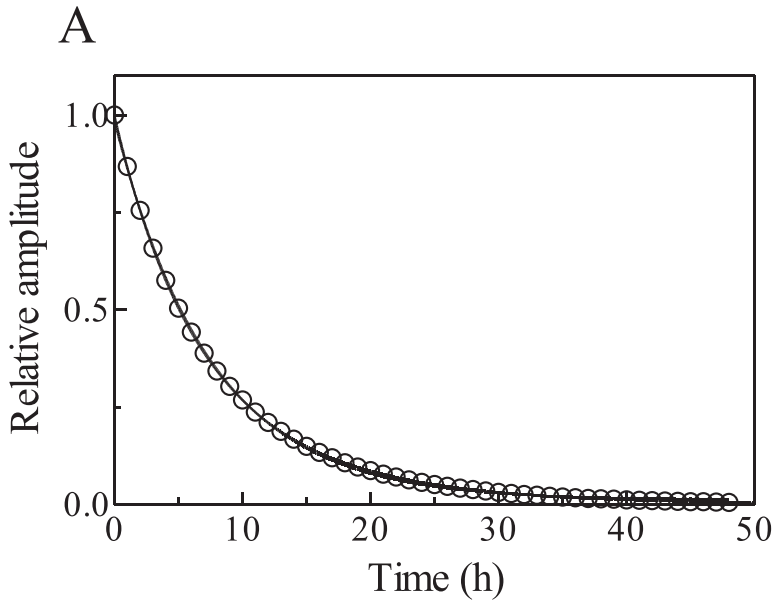

B
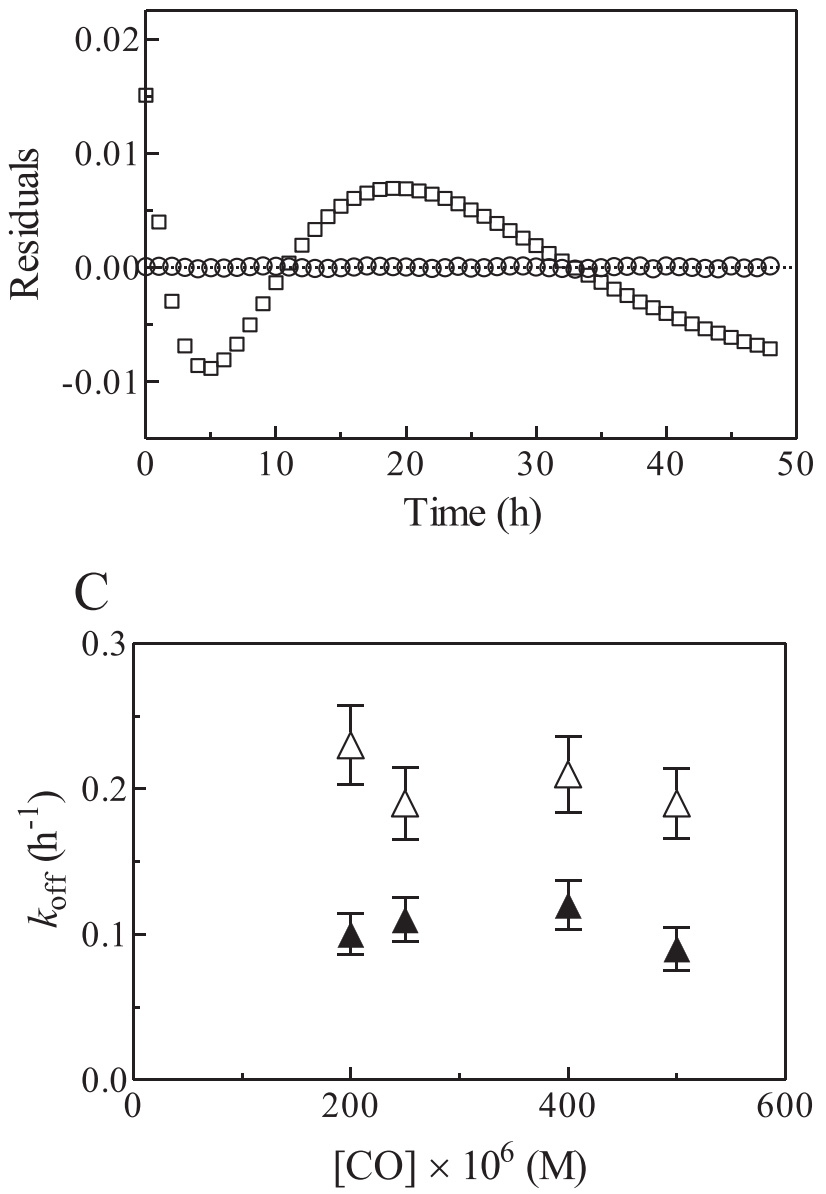

Fig. 2. Kinetics of $\mathrm{NO}$ dissociation from $\mathrm{Hp} 2-2: \mathrm{Hb}(\mathrm{II})-\mathrm{NO}$, at $\mathrm{pH} 7.0$ and $20.0^{\circ} \mathrm{C}$. (A) Time course of NO dissociation from Hp2-2:Hb(II)-NO. The CO concentration was $5.0 \times 10^{-4} \mathrm{M}$. The time course analysis according to eq. (1) allowed to determine the values of $k_{\text {off (NO) } 1}=1.9 \times 10^{-1} \mathrm{~h}^{-1}\left(=5.3 \times 10^{-5}\right.$ $\left.\mathrm{s}^{-1}\right), A_{1}=0.51, k_{\text {off }(\mathrm{NO}) 2}=9.0 \times 10^{-2} \mathrm{~h}^{-1}\left(=2.5 \times 10^{-5} \mathrm{~s}^{-1}\right)$. and $A_{2}=0.49$. The time course analysis according to eq. (2) allowed to determine the values of $k_{\text {off (NO) }}=1.3 \times 10^{-1} \mathrm{~h}^{-1}\left(=3.6 \times 10^{-5} \mathrm{~s}^{-1}\right)$ and $A=1.0$. (B) Residuals obtained from the non-linear least-squares fitting with one (squares; eq. (2)) and two (circles; eq. (1)) exponential(s) of data referring to NO dissociation from $\mathrm{Hp} 2-2: \mathrm{Hb}(\mathrm{II})-\mathrm{NO}$. (C) Dependence of the first order rate constant for NO dissociation from $\mathrm{Hp} 2-2: \mathrm{Hb}(\mathrm{II})-\mathrm{NO}$ on the $\mathrm{CO}$ concentration. The average values of $k_{\text {off (NO)1 }}$ and $k_{\text {off(NO)2 }}$ are $2.1 \times 10^{-1} \mathrm{~h}^{-1}\left(=5.8 \times 10^{-5} \mathrm{~s}^{-1}\right)$ and $1.1 \times$ $10^{-1} \mathrm{~h}^{-1}\left(=3.1 \times 10^{-5} \mathrm{~s}^{-1}\right)$, respectively. The Hp1-1:Hb(II)-NO concentration was $4.6 \times 10^{-6} \mathrm{M}$. The dithionite concentration was $2.0 \times 10^{-3} \mathrm{M}$. 
Table 1

Values of $k_{\mathrm{on}(\mathrm{NO})}$ and $k_{\mathrm{off}(\mathrm{NO})}$ for (de)nitrosylation of $\mathrm{Hb}(\mathrm{II})(-\mathrm{NO}), \mathrm{Hp} 1-1: \mathrm{Hb}(\mathrm{II})$ (-NO), Hp2-2:Hb(II)(-NO), $\alpha(\mathrm{II})(-\mathrm{NO})$, and $\beta(\mathrm{II})(-\mathrm{NO})$ species.

\begin{tabular}{|c|c|c|c|c|}
\hline Heme-protein & $\begin{array}{l}k_{\mathrm{on}(\mathrm{NO})}\left(\mathrm{M}^{-1}\right. \\
\left.\mathrm{s}^{-1}\right)\end{array}$ & $\begin{array}{l}k_{\text {off(nO) }} \\
\left(\mathrm{s}^{-1}\right)\end{array}$ & $k_{\text {off1(NO) }}\left(\mathrm{s}^{-1}\right)$ & $k_{\text {off2(NO) }}\left(\mathrm{s}^{-1}\right)$ \\
\hline $\begin{array}{l}\mathrm{Hb}(\mathrm{II})(-\mathrm{NO})+\mathrm{IHP} \\
\quad \text { (T-state) }\end{array}$ & $2.5 \times 10^{7}$ & & $\begin{array}{l}3.1 \times 10^{-3 b} \\
1.1 \times 10^{-3} \mathrm{c}\end{array}$ & $\begin{array}{l}9.0 \times 10^{-5 b} \\
4.2 \times 10^{-4 c}\end{array}$ \\
\hline $\begin{array}{l}\mathrm{Hb}(\mathrm{II})(-\mathrm{NO})(\mathrm{R}- \\
\text { state) }\end{array}$ & $2.5 \times 10^{7}$ & $\begin{array}{l}1.8 \times \\
10^{-5 b}\end{array}$ & & \\
\hline $\begin{array}{l}\text { Hp1-1:Hb(II) } \\
\quad(-\mathrm{NO})\end{array}$ & $\begin{array}{l}(1.1 \pm 0.1) \times \\
10^{7} \mathrm{~d}\end{array}$ & & $\begin{array}{l}(6.4 \pm 0.8) \times \\
10^{-5 e}\end{array}$ & $\begin{array}{l}(3.6 \pm 0.5) \times \\
10^{-5 e}\end{array}$ \\
\hline $\begin{array}{l}\text { Hp1-1:Hb(II) } \\
\quad(-\mathrm{NO})+\mathrm{IHP}^{\mathrm{e}}\end{array}$ & & & $\begin{array}{l}(6.3 \pm 0.7) \times \\
10^{-5}\end{array}$ & $\begin{array}{l}(3.1 \pm 0.4) \times \\
10^{-5}\end{array}$ \\
\hline $\begin{array}{l}\mathrm{Hp} 1-1: \mathrm{Hb}(\mathrm{II}) \\
\quad(-\mathrm{NO})+\mathrm{BZF}^{\mathrm{e}}\end{array}$ & & & $\begin{array}{l}(7.7 \pm 0.9) \times \\
10^{-5}\end{array}$ & $\begin{array}{l}(2.9 \pm 0.5) \times \\
10^{-5}\end{array}$ \\
\hline $\begin{array}{l}\mathrm{Hp} 2-2: \mathrm{Hb}(\mathrm{II}) \\
\quad(-\mathrm{NO})\end{array}$ & $\begin{array}{l}(9.3 \pm 0.9) \times \\
10^{6 \mathrm{f}}\end{array}$ & & $\begin{array}{l}(5.8 \pm 0.8) \times \\
10^{-5} \mathrm{e}\end{array}$ & $\begin{array}{l}(3.1 \pm 0.6) \times \\
10^{-5} \mathrm{e}\end{array}$ \\
\hline $\begin{array}{l}\mathrm{Hp} 2-2: \mathrm{Hb}(\mathrm{II}) \\
\quad(-\mathrm{NO})+\mathrm{IHP}^{\mathrm{e}}\end{array}$ & & & $\begin{array}{l}(6.3 \pm 0.7) \times \\
10^{-5}\end{array}$ & $\begin{array}{l}(3.5 \pm 0.4) \times \\
10^{-5}\end{array}$ \\
\hline $\begin{array}{l}\mathrm{Hp} 2-2: \mathrm{Hb}(\mathrm{II}) \\
\quad(-\mathrm{NO})+\mathrm{BZF}^{\mathrm{e}}\end{array}$ & & & $\begin{array}{l}(6.9 \pm 0.8) \times \\
10^{-5}\end{array}$ & $\begin{array}{l}(3.8 \pm 0.5) \times \\
10^{-5}\end{array}$ \\
\hline$\alpha(\mathrm{II})(-\mathrm{NO})$ chains $^{\mathrm{a}}$ & $2.4 \times 10^{7}$ & $\begin{array}{l}4.6 \times \\
10^{-5}\end{array}$ & & \\
\hline$\beta(\mathrm{II})(-\mathrm{NO})$ chains $^{\text {a }}$ & $2.4 \times 10^{7}$ & $\begin{array}{l}2.2 \times \\
10^{-5}\end{array}$ & & \\
\hline
\end{tabular}

${ }^{\mathrm{a}} \mathrm{pH} 7.0$ and $20.0^{\circ} \mathrm{C}$. From [30].

b $\mathrm{pH} 7.0$ and $20.0^{\circ} \mathrm{C}$. From [33].

c $\mathrm{pH} 7.4$ and $20.0^{\circ} \mathrm{C}$. From [51]. The slower rate refers specifically to pentacoordinated $\alpha$-chains of tetrameric $\mathrm{Hb}(\mathrm{II})$-NO.

${ }^{\mathrm{d}} \mathrm{pH} 7.5$ and $20.0^{\circ} \mathrm{C}$. From [21].

e $\mathrm{pH} 7.0$ and $20.0^{\circ} \mathrm{C}$. Present study.

${ }^{f} \mathrm{pH} 7.6$ and $20.0^{\circ} \mathrm{C}$. From [21].

where $A=1$.

The absorbance spectra of $\mathrm{Hp} 1-1: \mathrm{Hb}(\mathrm{II})-\mathrm{NO}$ and $\mathrm{Hp} 2-2: \mathrm{Hb}(\mathrm{II})-\mathrm{NO}$ were recorded between 380 and $450 \mathrm{~nm}$ in the absence and presence of IHP and BZF (final concentration, $\left.2.0 \times 10^{-2} \mathrm{M}\right)$, at pH $7.0\left(5.0 \times 10^{-2}\right.$ $\mathrm{M}$ phosphate buffer), and $20.0^{\circ} \mathrm{C}[17,39,40]$. Of note, IHP and BZF shift the quaternary equilibrium of tetrameric $\mathrm{Hb}$ (II)-NO from the hexacoordinated high affinity R-state to the penta-coordinated low affinity T-state. IHP- and BZF-mediated changes of the quaternary equilibrium of $\mathrm{Hb}(\mathrm{II})$-NO can be easily detected by absorbance spectroscopy $[17,39,40]$.

The results are given as mean values of at least four experiments plus or minus the corresponding standard deviation. All data were analyzed using the GraphPad Prism program, version 5.03 (GraphPad Software, La Jolla, CA, USA).

Molecular docking simulations were only carried out for IHP (RCSB PDB ligand ID: IHP) binding to Hb(II)-CO (PDB ID: 2DN3) [41] using the software DockingApp [42], a graphical interface for AutoDock Vina [43], limiting the grid box to the $\mathrm{Hb}(\mathrm{II})$-CO:IHP interacting residues [44]. The IHP structure was retrieved from RCSB PDB (ligand ID: IHP) in sdf format. Subsequently it was first converted in pdb format, using The Open Babel Package version 2.4.1 [45], and then in pdbqt format through the MGLTools script "prepare_ligand4.py" [46]. The docking results for the $\mathrm{Hb}(\mathrm{II})$-CO:IHP complex were analyzed by the molecular graphics software UCSF-Chimera version 1.13.1 [47]. Moreover, amino acid residues recognizing BZF bound to $\mathrm{Hb}(\mathrm{II})-\mathrm{O}_{2}$ (PDB ID: 5X2S and 5X2T) [48] were identified with the Protein-Ligand Interaction Profiler web server (https://projects.biotec.tu-dresden.de/plip-web/plip/index) [49].

\section{Results and discussion}

The NO dissociation reaction from $\mathrm{Hp} 1-1: \mathrm{Hb}(\mathrm{II})-\mathrm{NO}$ and $\mathrm{Hp} 2-2: \mathrm{Hb}$ (II)-NO through displacement by $\mathrm{CO}$ (in the presence of dithionite) conforms to the minimum reaction mechanism depicted in Scheme 1. Of note, the rate of NO dissociation from $\mathrm{Hp} 1-1: \mathrm{Hb}(\mathrm{II})-\mathrm{NO}$ and $\mathrm{Hp} 2-2: \mathrm{Hb}$ (II)-NO represents the rate limiting step of the whole process. Thus, upon
Table 2

Effect of IHP and BZF on values of $\lambda_{\max }$ and $\varepsilon$ of the absorbance spectra of $\mathrm{Hb}(\mathrm{II})-$ NO, Hp1-1:Hb(II)-NO, and Hp2-2:Hb(II)-NO in the Soret region.

\begin{tabular}{|c|c|c|}
\hline Heme-protein & $\lambda_{\max }(\mathrm{nm})$ & $\varepsilon\left(\mathrm{mM}^{-1} \mathrm{~cm}^{-1}\right)$ \\
\hline \multirow[t]{3}{*}{$\mathrm{Hb}(\mathrm{II})(-\mathrm{NO})+\mathrm{IHP}$ (R-state) } & $417.0^{\mathrm{a}}$ & $133^{\mathrm{a}}$ \\
\hline & $416.7^{b}$ & $131^{b}$ \\
\hline & $417.2^{c}$ & $131^{c}$ \\
\hline \multirow[t]{3}{*}{$\mathrm{Hb}(\mathrm{II})(-\mathrm{NO})+\mathrm{IHP}$ (T-state) } & $415.9^{\mathrm{a}}$ & $98^{\mathrm{a}}$ \\
\hline & $415.2^{b}$ & $99^{\mathrm{b}}$ \\
\hline & $416.2^{c}$ & $101.8^{c}$ \\
\hline \multirow[t]{2}{*}{$\mathrm{Hb}(\mathrm{II})(-\mathrm{NO})+\mathrm{BZF}$ (T-state) } & $416.9^{\mathrm{a}}$ & $101.3^{\mathrm{a}}$ \\
\hline & $416.2^{c}$ & $105.2^{c}$ \\
\hline $\mathrm{Hp} 1-1: \mathrm{Hb}(\mathrm{II})(-\mathrm{NO})^{\mathrm{a}}$ & 417.2 & 131 \\
\hline $\mathrm{Hp} 1-1: \mathrm{Hb}(\mathrm{II})(-\mathrm{NO})+\mathrm{IHP}^{\mathrm{a}}$ & 416.8 & 129 \\
\hline $\mathrm{Hp} 1-1: \mathrm{Hb}(\mathrm{II})(-\mathrm{NO})+\mathrm{BZF}^{\mathrm{a}}$ & 417.1 & 132 \\
\hline $\mathrm{Hp} 2-2: \mathrm{Hb}(\mathrm{II})(-\mathrm{NO})^{\mathrm{a}}$ & 416.9 & 133 \\
\hline $\mathrm{Hp} 2-2: \mathrm{Hb}(\mathrm{II})(-\mathrm{NO})+\mathrm{IHP}^{\mathrm{a}}$ & 416.6 & 131 \\
\hline $\mathrm{Hp} 2-2: \mathrm{Hb}(\mathrm{II})(-\mathrm{NO})+\mathrm{BZF}^{\mathrm{a}}$ & 416.8 & 130 \\
\hline
\end{tabular}

NO dissociation, $\mathrm{Hp} 1-1: \mathrm{Hb}(\mathrm{II})$ and $\mathrm{Hp} 2-2: \mathrm{Hb}(\mathrm{II})$ react much more rapidly with $\mathrm{CO}$ than with $\mathrm{NO}$; in fact, $k_{\mathrm{on}(\mathrm{CO})} \times[\mathrm{CO}]$ ranges from $3.8 \times$ $10^{2} \mathrm{~s}^{-1}$ to $2.6 \times 10^{3} \mathrm{~s}^{-1}$ (i.e., [CO] ranges from $2.0 \times 10^{-4} \mathrm{M}$ to $5.0 \times$ $10^{-4} \mathrm{M}$ and $k_{\mathrm{on}(\mathrm{CO})}=1.9 \times 10^{6} \mathrm{M}^{-1} \mathrm{~s}^{-1}$ and $5.2 \times 10^{6} \mathrm{M}^{-1} \mathrm{~s}^{-1}$ for $\mathrm{Hp} 1-1: \mathrm{Hb}(\mathrm{II})$ and $\mathrm{Hp} 2-2: \mathrm{Hb}(\mathrm{II})$, respectively) [11] whereas $k_{\mathrm{on}(\mathrm{NO})} \times$ [NO] ranges from $4.5 \times 10^{1} \mathrm{~s}^{-1}$ to $5.5 \times 10^{1} \mathrm{~s}^{-1}$ (i.e., $[\mathrm{NO}]=5.0 \times 10^{-6}$ $\mathrm{M}$ and $k_{\mathrm{on}(\mathrm{NO})}=1.1 \times 10^{7} \mathrm{M}^{-1} \mathrm{~s}^{-1}$ and $9.3 \times 10^{6} \mathrm{M}^{-1} \mathrm{~s}^{-1}$ for $\mathrm{Hp} 1-1: \mathrm{Hb}$ (II) and $\mathrm{Hp} 2-2: \mathrm{Hb}(\mathrm{II})$, respectively) [21], decreasing even further because of NO consumption by sodium dithionite [30,50], thus rendering even more reliable the determination of the NO dissociation rate constant.

Over the whole $\mathrm{CO}$ concentration range explored (final concentration, $2.0 \times 10^{-4} \mathrm{M}$ to $5.0 \times 10^{-4} \mathrm{M}$ ), the time course of Hp1-1:Hb(II)$\mathrm{NO}$ and $\mathrm{Hp} 2-2: \mathrm{Hb}(\mathrm{II})-\mathrm{NO}$ conversion to $\mathrm{Hp} 1-1: \mathrm{Hb}(\mathrm{II})-\mathrm{CO}$ and $\mathrm{Hp} 2-2$ : $\mathrm{Hb}(\mathrm{II})-\mathrm{CO}$, respectively, by $\mathrm{CO}$ (in the presence of dithionite) corresponds to a bi-exponential process, the amplitude of both phases ranges from $47 \pm 5 \%$ to $52 \pm 5 \%$ of the total amplitude (Figs. 1 and 2, panel A, and Fig. 2 SM and 3 SM of Supplementary Material). Values of the firstorder rate constants for $\mathrm{Hp} 1-1: \mathrm{Hb}(\mathrm{II})-\mathrm{NO}$ and $\mathrm{Hp} 2-2: \mathrm{Hb}(\mathrm{II})-\mathrm{NO}$ denitrosylation (i.e., for $\mathrm{Hp} 1-1: \mathrm{Hb}(\mathrm{II})-\mathrm{CO}$ and $\mathrm{Hp} 2-2: \mathrm{Hb}(\mathrm{II})-\mathrm{CO}$ formation; $\left.k_{\text {off(NO) }}\right)$ are wavelength- and [CO]-independent.

The values of the fast and slow phase of NO dissociation from Hp1-1: $\mathrm{Hb}(\mathrm{II})-\mathrm{NO}, \mathrm{Hp} 2-2: \mathrm{Hb}(\mathrm{II})-\mathrm{NO}$ (i.e., $k_{\mathrm{off}(\mathrm{NO}) 1}$ and $k_{\mathrm{off}(\mathrm{NO}) 2}$, respectively) (present study): (i) are unaffected by IHP and BZF (Table 1), (ii) correspond to those of isolated $\alpha$ (II)-NO and $\beta($ II)-NO chains, respectively, (iii) match with those of NO dissociation from the R-state of $\mathrm{Hb}(\mathrm{II})-\mathrm{NO}$, and (iv) differ from those for the denitrosylation of the T-state of $\mathrm{Hb}(\mathrm{II})-\mathrm{NO}$ $[30,33,51]$ (Table 1). In both $\mathrm{Hp}: \mathrm{Hb}(\mathrm{II})-\mathrm{NO}$ complexes no evidence can be detected of the penta-coordinate nitrosylated $\alpha$-chain, which is known to have a NO dissociation rate constant faster than in the R-state $[30,33,51]$ and a low absorbance in the Soret region $[17,39,40]$. This is not unexpected, since in the $\mathrm{Hp}: \mathrm{Hb}$ complexes dimers are in the $\mathrm{R}$ quaternary conformation, while penta-coordination seems associated to the low affinity T-structure [30,33,51].

On the other hand, it is known that also in the R-state tetrameric $\mathrm{Hb}$ is able to bind allosteric effectors, such as inositol hexakisphosphate (IHP) and bezafibrate (BZF), displaying both functional [52,53] and spectroscopic effects $[17,39,40]$, envisaging structural arrangement of both subunits [40,52-54]. However, in the case of $\mathrm{Hp}: \mathrm{Hb}$ complexes neither functional nor spectroscopic effects appear associated to the addition of either IHP or BZF (Tables 1 and 2), envisaging the possibility that either they do not bind the dimer associated to Hp or else they do not affect the structural arrangement of the dimers in the $\mathrm{Hp}: \mathrm{Hb}$ complexes.

The molecular bases of a lack of effect of IHP and BZF on NO 


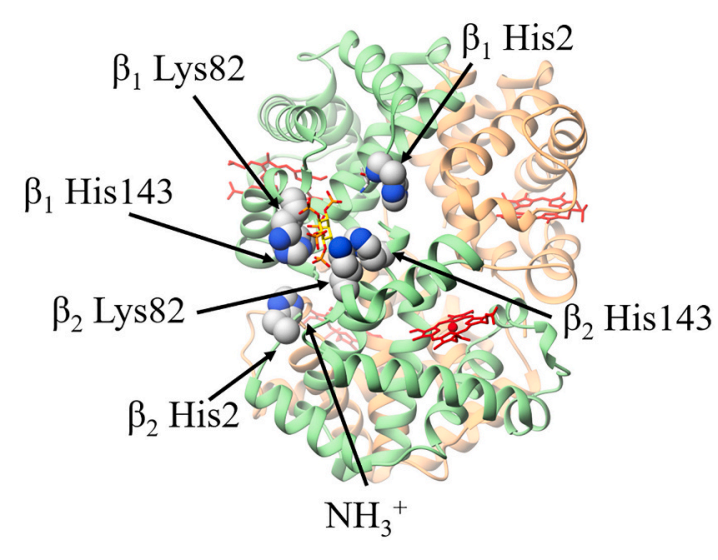

IHP binding to $\mathrm{Hb}$

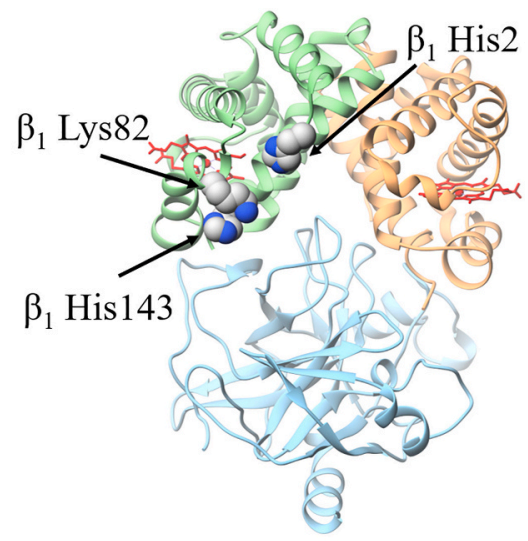

$\mathrm{Hp}: \mathrm{Hb}$

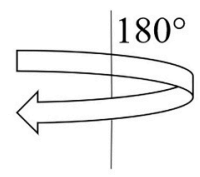

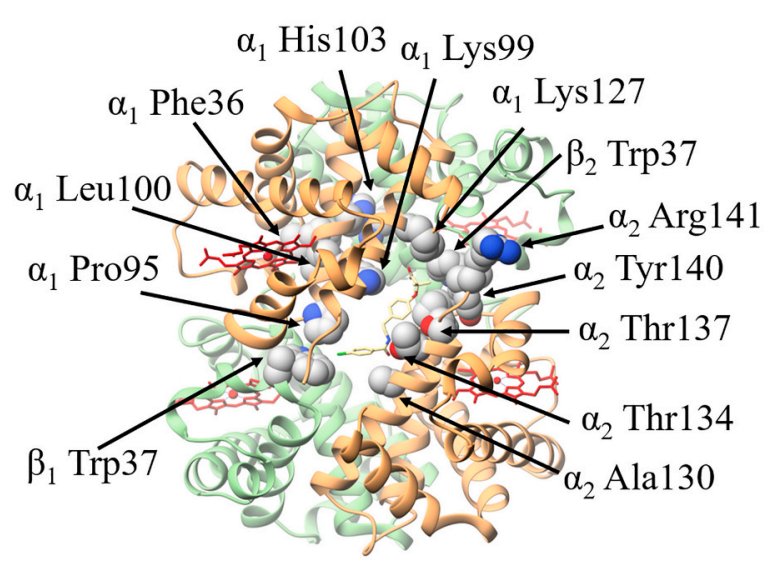

BZF binding to $\mathrm{Hb}$

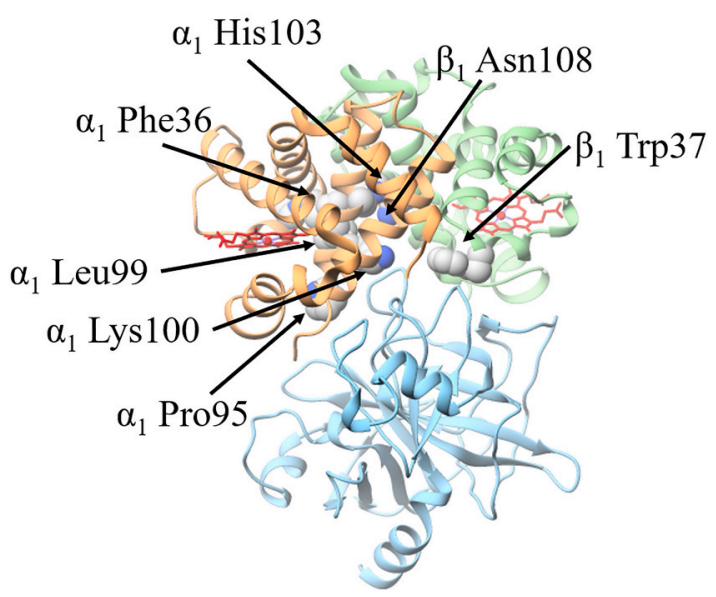

$\mathrm{Hp}: \mathrm{Hb}$

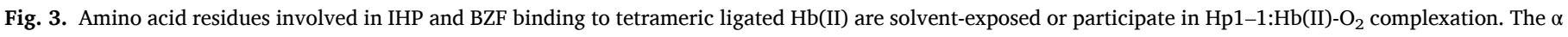

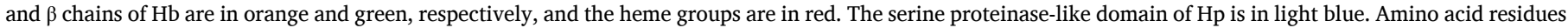

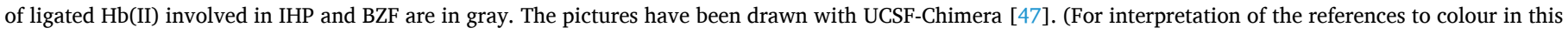
figure legend, the reader is referred to the web version of this article.)

dissociation from $\mathrm{Hp} 1-1: \mathrm{Hb}(\mathrm{II})-\mathrm{NO}, \mathrm{Hp} 2-2: \mathrm{Hb}(\mathrm{II})-\mathrm{NO}$ and on the absorbance spectroscopic properties of $\mathrm{Hp} 1-1: \mathrm{Hb}(\mathrm{II})-\mathrm{NO}, \mathrm{Hp} 2-2: \mathrm{Hb}(\mathrm{II})-$ NO have been investigated through molecular docking analyses. IHP binding to tetrameric $\mathrm{Hb}$ involves the $\beta_{1} N$-terminus, $\beta_{1}$ and $\beta_{2}$ His $2, \beta_{1}$ and $\beta_{2}$ Lys82, and $\beta_{1}$ and $\beta_{2}$ His143 [44]. The results of molecular docking simulations do not evidence binding of IHP in the vicinity of the above mentioned residues (Fig. 3). Although the $\beta_{1} N$-terminus, $\beta_{1}$ His 2 , $\beta_{1}$ Lys82, and $\beta_{1}$ His143 are solvent exposed in the Hp:Hb complex, the absence of IHP binding to the $\mathrm{Hp}: \mathrm{Hb}$ complex may reflect the disruption of the IHP cleft that is built up by both the $\alpha_{1} \beta_{1}$ and $\alpha_{2} \beta_{2}$ dimers in tetrameric $\mathrm{Hb}$. In the case of BZF binding to tetrameric $\mathrm{Hb}$ (Fig. 3), the situation is more complex, since multiple ligand binding have been reported $[48,55,56]$. In fact, BZF is able to bind one $\beta$ and two $\alpha$ subunits of $\mathrm{Hb}(\mathrm{II})-\mathrm{O}_{2}[48,55]$ interacting with the amino acids residues $\beta_{2} \operatorname{Trp} 37, \alpha_{1}$ Lys127, $\alpha_{1}$ and $\alpha_{2}$ Pro95 and $\alpha_{2}$ Tyr140, at pH 6.5 (PDB ID: 5X2S) [48] and with $\beta_{1}$ Trp37, $\alpha_{1}$ Lys127, $\alpha_{2}$ Ala130 and $\alpha_{2}$ Thr134, at pH 7.2 (PDB
ID: 5X2T) [48] (Fig. 3). Thus, the loss of ability of the Hp:Hb complexes to bind BZF may reflect: (i) the involvement of residues $\alpha_{1}$ Phe36, $\alpha_{1}$ Pro95, $\alpha_{1}$ Lys99, $\alpha_{1}$ Leu100, $\alpha_{1}$ His103, $\beta_{1}$ Trp37, and $\beta_{1}$ Asn108 in the $\mathrm{Hp} 1-1: \mathrm{Hb}(\mathrm{II})-\mathrm{O}_{2}$ complexation [8] and (ii) residues $\beta_{2}$ Trp37, $\alpha_{2}$ Pro95, $\alpha_{2}$ Ala130, $\alpha_{2}$ Thr134, $\alpha_{2}$ Thr137, $\alpha_{2}$ Tyr140, and $\alpha_{2}$ Arg141 do not participate to BZF recognition in tetrameric Hb [48] (Fig. 3). Since BZF interacts with the $E$-helix of the $\alpha$-subunit in the tetrameric R-state of $\mathrm{Hb}$ (II)-CO [56], it cannot be excluded that BZF could recognize the $\mathrm{Hp}: \mathrm{Hb}$ complexes in a similar fashion without affecting the reactivity and the absorbance spectroscopic properties of $\mathrm{Hp}: \mathrm{Hb}$ complexes (Tables 1 and 2).

A closer view of the biphasic dissociation rate constants casts some light on the different free energy barriers between the $\alpha$ and $\beta$ subunits for the NO detachment from the nitrosylated heme-Fe(II) atom and for the ligand exit pathway. In the fully NO-bound $\mathrm{Hb}$ the energy barrier for NO dissociation from $\alpha$-chain (i.e., $96.9 \mathrm{~kJ} / \mathrm{mol}$ ) is about $1.8 \mathrm{~kJ} / \mathrm{mol}$ 
Table 3

Values of kinetic and thermodynamic parameters for $\mathrm{CO}, \mathrm{O}_{2}$ and $\mathrm{NO}$ dissociation from ligated $\mathrm{Hb}(\mathrm{II})$ species.

\begin{tabular}{|c|c|c|c|c|c|c|c|}
\hline $\begin{array}{l}\text { Heme- } \\
\text { protein }\end{array}$ & Ligand & $\begin{array}{l}k_{\mathrm{off}} \\
\left(\mathrm{s}^{-1}\right)\end{array}$ & $\begin{array}{l}k_{\mathrm{off} 1} \\
\left(\mathrm{~s}^{-1}\right)\end{array}$ & $\begin{array}{l}k_{\mathrm{off} 2} \\
\left(\mathrm{~s}^{-1}\right)\end{array}$ & $\begin{array}{l}\Delta G^{\ddagger} \\
(\mathrm{kJ} / \\
\mathrm{mol})^{\mathrm{a}}\end{array}$ & $\begin{array}{l}\Delta G_{1}^{\ddagger} \\
(\mathrm{kJ} / \\
\mathrm{mol})^{\text {a }}\end{array}$ & $\begin{array}{l}\Delta G_{2}^{\ddagger} \\
(\mathrm{kJ} / \\
\mathrm{mol})^{\mathrm{a}}\end{array}$ \\
\hline $\begin{array}{c}\mathrm{Hb}(\mathrm{II}) \mathrm{T}- \\
\text { state }^{\mathrm{b}}\end{array}$ & $\mathrm{CO}$ & $\sim 0.2$ & & & 76.6 & & \\
\hline $\begin{array}{l}\mathrm{Hb}(\mathrm{II}) \mathrm{R}- \\
\text { state }^{c}\end{array}$ & $\mathrm{CO}$ & & $\begin{array}{l}(1.1 \pm \\
0.2) \times \\
10^{-2}\end{array}$ & $\begin{array}{l}(8.0 \pm \\
0.2) \times \\
10^{-3}\end{array}$ & & $\begin{array}{l}83.6 \\
\pm 0.5\end{array}$ & $\begin{array}{l}84.4 \\
\pm 0.3\end{array}$ \\
\hline $\begin{array}{l}\text { Hp1-1: } \\
\text { Hb(II) } \\
\text { d }\end{array}$ & $\mathrm{CO}$ & & $\begin{array}{l}(1.4 \pm \\
0.2) \times \\
10^{-2}\end{array}$ & $\begin{array}{l}(6.2 \pm \\
0.8) \times \\
10^{-3}\end{array}$ & & $\begin{array}{l}83.0 \\
\pm 0.3\end{array}$ & $\begin{array}{l}85.0 \\
\pm 0.4\end{array}$ \\
\hline $\begin{array}{l}\text { Hp2-2: } \\
\qquad \begin{array}{l}\text { Hb(II) } \\
\text { d }\end{array}\end{array}$ & $\mathrm{CO}$ & & $\begin{array}{l}(1.3 \pm \\
0.2) \times \\
10^{-2}\end{array}$ & $\begin{array}{l}(7.3 \pm \\
0.9) \times \\
10^{-3}\end{array}$ & & $\begin{array}{l}83.2 \\
\pm 0.3\end{array}$ & $\begin{array}{l}84.6 \\
\pm 0.4\end{array}$ \\
\hline $\begin{array}{l}\alpha(\mathrm{II}) \\
\quad \text { chains } \\
\mathrm{b}\end{array}$ & $\mathrm{CO}$ & $\begin{array}{l}1.3 \\
\times \\
10^{-2}\end{array}$ & & & 83.2 & & \\
\hline $\begin{array}{l}\beta(\text { II }) \\
\quad \text { chains } \\
\text { b }\end{array}$ & $\mathrm{CO}$ & $\begin{array}{l}8.0 \\
\times \\
10^{-3}\end{array}$ & & & 84.4 & & \\
\hline $\begin{array}{c}\text { Hb(II) T- } \\
\text { state }^{e}\end{array}$ & $\mathrm{O}_{2}$ & & $\begin{array}{l}(2.5 \pm \\
0.1) \times \\
10^{3}\end{array}$ & $\begin{array}{l}(1.8 \pm \\
0.1) \times \\
10^{2}\end{array}$ & & $\begin{array}{l}53.7 \\
\pm 0.2\end{array}$ & $\begin{array}{l}60.0 \\
\pm 0.3\end{array}$ \\
\hline $\begin{array}{l}\text { Hb(II) R- } \\
\text { state }^{c}\end{array}$ & $\mathrm{O}_{2}$ & & $\begin{array}{l}(4.0 \pm \\
0.8) \times \\
10^{1}\end{array}$ & $\begin{array}{l}(1.2 \pm \\
0.2) \times \\
10^{1}\end{array}$ & & $\begin{array}{l}63.7 \\
\pm 0.5\end{array}$ & $\begin{array}{l}66.6 \\
\pm 0.5\end{array}$ \\
\hline $\begin{array}{l}\text { Hp1-1: } \\
\qquad \begin{array}{l}\text { Hb(II) } \\
\text { f }\end{array}\end{array}$ & $\mathrm{O}_{2}$ & & $\begin{array}{l}(2.8 \pm \\
0.3) \times \\
10^{1}\end{array}$ & $\begin{array}{l}(1.6 \pm \\
0.2) \times \\
10^{1}\end{array}$ & & $\begin{array}{l}64.6 \\
\pm 0.3\end{array}$ & $\begin{array}{l}65.9 \\
\pm 0.3\end{array}$ \\
\hline 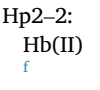 & $\mathrm{O}_{2}$ & & $\begin{array}{l}(2.7 \pm \\
0.3) \times \\
10^{1}\end{array}$ & $\begin{array}{l}(1.4 \pm \\
0.2) \times \\
10^{1}\end{array}$ & & $\begin{array}{l}64.7 \\
\pm 0.3\end{array}$ & $\begin{array}{l}66.2 \\
\pm 0.4\end{array}$ \\
\hline $\begin{array}{l}\alpha(\mathrm{II}) \\
\quad \text { chains } \\
\mathrm{b}\end{array}$ & $\mathrm{O}_{2}$ & $\begin{array}{l}2.8 \\
\times 10^{1}\end{array}$ & & & 64.6 & & \\
\hline $\begin{array}{l}\beta(\mathrm{II}) \\
\quad \text { chains } \\
\mathrm{b}\end{array}$ & $\mathrm{O}_{2}$ & $\begin{array}{l}1.6 \\
\times 10^{1}\end{array}$ & & & 65.9 & & \\
\hline $\begin{array}{l}\mathrm{Hb}(\mathrm{II}) \\
\text { (T- } \\
\text { state) }\end{array}$ & NO & & $\begin{array}{l}3.1 \times \\
10^{-3} \mathrm{~g} \\
{ }^{\mathrm{h}} 1.1 \times \\
10^{-3}\end{array}$ & $\begin{array}{l}9.0 \times \\
10^{-5} \mathrm{~g} \\
4.2 \times \\
10^{-4 h}\end{array}$ & & $\begin{array}{l}89.4 \\
89.2\end{array}$ & $\begin{array}{l}95.3 \\
91.5\end{array}$ \\
\hline $\begin{array}{l}\mathrm{Hb} \text { (II) R- } \\
\text { state }^{\mathrm{g}}\end{array}$ & NO & $\begin{array}{l}1.8 \\
\times \\
10^{-5}\end{array}$ & & & 99.2 & & \\
\hline $\begin{array}{l}\text { Hp1-1: } \\
\text { Hb(II) } \\
\text { i }\end{array}$ & NO & & $\begin{array}{l}(6.4 \pm \\
0.8) \times \\
10^{-5}\end{array}$ & $\begin{array}{l}(3.6 \pm \\
0.5) \times \\
10^{-5}\end{array}$ & & $\begin{array}{l}96.1 \\
\pm 0.3\end{array}$ & $\begin{array}{l}97.5 \\
\pm 0.4\end{array}$ \\
\hline $\begin{array}{l}\text { Hp2-2: } \\
\text { Hb(II) } \\
\text { i }\end{array}$ & NO & & $\begin{array}{l}(5.8 \pm \\
0.8) \times \\
10^{-5}\end{array}$ & $\begin{array}{l}(3.1 \pm \\
0.6) \times \\
10^{-5}\end{array}$ & & $\begin{array}{l}96.3 \\
\pm 0.3\end{array}$ & $\begin{array}{l}97.9 \\
\pm 0.5\end{array}$ \\
\hline $\begin{array}{l}\alpha(\text { II }) \\
\quad \text { chains }\end{array}$ & NO & $\begin{array}{l}4.6 \\
\times \\
10^{-5}\end{array}$ & & & 96.9 & & \\
\hline $\begin{array}{l}\beta(\text { II }) \\
\quad \text { chains } \\
j\end{array}$ & NO & $\begin{array}{l}2.2 \\
\times \\
10^{-5}\end{array}$ & & & 98.7 & & \\
\hline
\end{tabular}

Footnote to Table 3 .

${ }^{\text {a }}$ Values of $\Delta G^{\ddagger}$ have been calculated according to the following equation: $\Delta G^{\ddagger}$ $=4.184 \times R \times T\left(\ln \left(10^{13}\right)-\ln k\right)$.

b $\mathrm{pH} 7.0$ and $20.0^{\circ} \mathrm{C}$. From [15].

c $\mathrm{pH} 7.4$ and $25.0^{\circ} \mathrm{C}$. From [34].

d $\mathrm{pH} 7.0$ and $20.0^{\circ} \mathrm{C}$. From [27].

e $\mathrm{pH} 7.0$ and $20.0^{\circ} \mathrm{C}$. From [32].

${ }^{f} \mathrm{pH} 7.0$ and $20.0^{\circ} \mathrm{C}$. From [23].

$\mathrm{g} \mathrm{pH} 7.0$ and $20.0^{\circ} \mathrm{C}$. From [33].

h $\mathrm{pH} 7.4$ and $20.0^{\circ} \mathrm{C}$. From [51]. The slower rate refers specifically to pentacoordinated $\alpha$-chains of tetrameric $\mathrm{Hb}$ (II)-NO.

${ }^{\mathrm{i}} \mathrm{pH} 7.0$ and $20.0^{\circ} \mathrm{C}$. Present study.

j $\mathrm{pH} 7.0$ and $20.0^{\circ} \mathrm{C}$. From [30]. lower than for $\beta$-chain denitrosylation (i.e., $98.7 \mathrm{~kJ} / \mathrm{mol}$ ). Of note, this difference $(i)$ can be observed between the two subunits within the $\mathrm{Hb}$ dimer both in $\mathrm{Hp} 1-1: \mathrm{Hb}(\mathrm{II})-\mathrm{NO}\left(\Delta \Delta G^{\ddagger}=1.4 \mathrm{~kJ} / \mathrm{mol}\right)$ and $\mathrm{Hp} 2-2: \mathrm{Hb}(\mathrm{II})-$ NO $\left(\Delta \Delta G^{\ddagger}=1.6 \mathrm{~kJ} / \mathrm{mol}\right)$, and (ii) is similar to that observed in other ligands of the ferrous form (i.e., $\mathrm{CO}$ and $\mathrm{O}_{2}$ ), displaying a ligandindependent value of $\Delta \Delta G^{\ddagger}=1.5 \pm 0.3 \mathrm{~kJ} / \mathrm{mol}$ (see Table 3).

The closely similar difference between the two subunits for free energy barriers of $\mathrm{CO}, \mathrm{O}_{2}$ and $\mathrm{NO}$ dissociation from R-state ligated $\mathrm{Hb}(\mathrm{II})$ (see Table 3) clearly indicates that the kinetic biphasicity has the same structural basis, even though various ligands are characterized by markedly different energy barriers. As a whole, we can state that the free energy barriers for the ligand dissociation from the ligand-bound heme (II) complexes and exit toward the bulk solvent are different for the two subunits in R-state ligated $\mathrm{Hb}(\mathrm{II})$ by $1.6 \pm 0.4 \mathrm{~kJ} / \mathrm{mol}$ (Table 3); this ligand-independent value refers to the different structural arrangement of the two subunits for any ligand exit pathway after the breaking of the Fe(II)-ligand bond.

On the other hand, the intrinsic values of $\Delta G^{\ddagger}$ greatly differ for various ligands (see Table 3), this reflecting instead the specific liganddependent interactions of each ligand with the distal site of the protein matrix in the R quaternary conformation. In this respect, data reported in Table 3 give an exhaustive description of the intrinsic subunit functional heterogeneity also in assembled dimers, clearly demonstrating that in assembled $\alpha_{1} \beta_{1}$ (as well as in $\alpha_{2} \beta_{2}$ ) dimers the structural arrangement of the two subunits does not show meaningful differences from isolated chains and/or tetramers (see Table 1 and [23,27]). However, the origin of the different ligand-dependent quaternary-linked effect remains elusive. In conclusion, unlike for $\mathrm{O}_{2}$ and $\mathrm{CO}$ $[32,34,55,57,58]$, the time-course for $\mathrm{NO}$ association to $\mathrm{Hb}$ (II) does not reflect the R-to-T allosteric transition [30], the cooperativity of $\mathrm{Hb}$ (II) nitrosylation depending uniquely on the ligand dissociation process. In fact, values of $k_{\text {off }}$ for NO dissociation from the T- and R-state of $\mathrm{Hb}$ (II) differ by 2 -orders of magnitude while the association rate constants are essentially identical for the two quaternary conformations (see Table 1). This strongly suggests that determinants for the different liganddependent quaternary-linked effects on ligand binding are multifactorial, underlying a much more complex regulatory mechanism.

\section{Declaration of Competing Interest}

The authors declare no conflict of interest.

\section{Acknowledgments}

Authors wish to thank Prof. Fabio Polticelli for critical reading of the manuscript. The grant of Dipartimenti di Eccellenza, MIUR (Legge 232/ 2016, Articolo 1, Comma 314-337) is gratefully acknowledged.

\section{Appendix A. Supplementary data}

Supplementary data to this article can be found online at https://doi. org/10.1016/j.jinorgbio.2020.111272.

\section{References}

[1] M. Kristiansen, J.H. Graversen, C. Jacobsen, O. Sonne, H.J. Hoffman, K. Law, S. K. Moestrup, Nature 409 (2001) 198-201.

[2] P.W. Buehler, B. Abraham, F. Vallelian, C. Linnemayr, C.P. Pereira, J.F. Cipollo, Y. Jia, M. Mikolajczyk, F.S. Boretti, G. Schoedon, A.I. Alayash, D.J. Schaer, Blood 113 (2009) 2578-2586.

[3] T. Kaempfer, E. Duerst, P. Gehrig, B. Roschitzki, D. Rutishauser, J. Grossmann, G. Schoedon, F. Vallelian, D.J. Schaer, J. Proteome, Res. 10 (2011) 2397-2408.

[4] J.H. Baek, F. D’Agnillo, F. Vallelian, C.P. Pereira, M.C. Williams, Y. Jia, D.J. Schaer, P.W. Buehler, J. Clin. Invest. 122 (2012) 1444-1458.

[5] A.I. Alayash, C.B. Andersen, S.K. Moestrup, L. Bülow, Trends Biotechnol. 31 (2013) 2-3.

[6] T.L. Mollan, Y. Jia, S. Banerjee, G. Wu, R.T. Kreulen, A.L. Tsai, J.S. Olson, A. L. Crumbliss, A.I. Alayash, Free Radic. Biol. Med. 69 (2014) 265-277. 
[7] C.B.F. Andersen, K. Stødkilde, K.L. Sæderup, A. Kuhlee, S. Raunser, J.H. Graversen, S.K. Moestrup, Antioxid. Redox Signal. 26 (2017) 814-831.

[8] A. di Masi, G. De Simone, C. Ciaccio, S. D’Orso, M. Coletta, P. Ascenzi, Mol. Asp. Med. 73 (2020) 100851.

[9] C.B.F. Andersen, M. Torvund-Jensen, M.J. Nielsen, C.L. de Oliveira, H.P. Hersleth, N.H. Andersen, J.S. Pedersen, G.R. Andersen, S.K. Moestrup, Nature 489 (2012) $456-459$.

[10] R.L. Nagel, J.B. Wittenberg, H.M. Ranney, Biochim. Biophys. Acta 100 (1965) 286-289.

[11] R.L. Nagel, Q.H. Gibson, J. Mol, Biol. 22 (1966) 249-255.

[12] M. Brunori, A. Alfsen, U. Saggese, E. Antonini, J. Wyman, J. Biol. Chem. 243 (1968) 2950-2954.

[13] Q.H. Gibson, L.J. Parkhurst, G. Geraci, J. Biol. Chem. 244 (1969) 4668-4676.

[14] E. Alfsen, E. Chiancone, E. Antonini, M. Waks, J. Wyman, Biochim. Biophys. Acta 207 (1970) 395-403.

[15] E. Antonini, M. Brunori, Hemoglobin and Myoglobin in their Reactions with Ligands, North Holland Publishing Co, Amsterdam, London, 1971.

[16] E. Chiancone, E. Antonini, M. Brunori, A. Alfsen, F. Lavialle, Biochem. J. 133 (1973) 205-207.

[17] M.F. Perutz, Annu. Rev. Biochem. 48 (1979) 327-386.

[18] A. Kurosky, D.R. Barnett, T.H. Lee, B. Touchstone, R.E. Hay, M.S. Arnott, B. H. Bowman, W.M. Fitch, Proc. Natl. Acad. Sci. U. S. A. 77 (1980) 3388-3392.

[19] I. Azarov, X. He, A. Jeffers, S. Basu, B. Ucer, R.R. Hantgan, A. Levy, D.B. KimShapiro, Nitric Oxide 18 (2008) 296-302.

[20] P. Ascenzi, M. Coletta, J. Phys, Chem. B 122 (2018) 11100-11107.

[21] P. Ascenzi, G. De Simone, F. Polticelli, M. Gioia, M. Coletta, J, Biol, Inorg. Chem. 23 (2018) 437-445.

[22] P. Ascenzi, G.R. Tundo, M. Coletta, J. Inorg. Biochem. 187 (2018) 116-122.

[23] P. Ascenzi, F. Polticelli, M. Coletta, Sci. Rep. 9 (2019) 6780.

[24] S.L. White, J. Biol. Chem. 250 (1975) 1263-1268.

[25] P. Ascenzi, A. di Masi, G. De Simone, M. Gioia, M. Coletta, J. Biol. Inorg. Chem. 24 (2019) 247-255.

[26] P. Ascenzi, G. De Simone, C. Ciaccio, M. Coletta, J. Inorg. Biochem. 202 (2020) 110814.

[27] P. Ascenzi, G. De Simone, G.R. Tundo, M. Coletta, J. Biol. Inorg. Chem. 25 (2020) $351-360$.

[28] M. Coletta, M. Angeletti, G. De Sanctis, L. Cerroni, B. Giardina, G. Amiconi, P. Ascenzi, Eur. J. Biochem. 235 (1996) 49-53.

[29] M. Hoshino, M. Maeda, R. Konishi, H. Seki, P.C. Ford, J. Am. Chem. Soc. 118 (1996) 5702-5707.

[30] E.G. Moore, Q.H. Gibson, J. Biol. Chem. 251 (1976) 2788-2794.

[31] P. Ascenzi, A. di Masi, F. Gullotta, M. Mattu, C. Ciaccio, M. Coletta, Biochem. Biophys. Res. Commun. 393 (2010) 196-200.
[32] C.A. Sawicki, Q.H. Gibson, J. Biol. Chem. 252 (1977) 7538-7547.

[33] V.S. Sharma, H.M. Ranney, J. Biol. Chem. 253 (1978) 6467-6472.

[34] K.D. Vandegriff, Y.C. Le Tellier, R.M. Winslow, R.J. Rohlfs, J.S. Olson, J. Biol. Chem. 266 (1991) 17049-17059.

[35] C.Y. Liau, K.C. Uengb, C.S. Lin, J. Chin, Chem. Soc-Taip 56 (2009) 859-866.

[36] Y. Jia, F. Wood, P.W. Buehler, A.I. .Alayash, PLoS One 8 (2013) e59841.

[37] C.E. Allen, M.P. Schmitt, J. Bacteriol. 197 (2015) 553-562.

[38] R.M. Barbosa, A.J. Lopes Jesus, R.M. Santos, C.L. Pereira, C.F. Marques, B.S. Rocha, N.R. Ferreira, A. Ledo, J. Laranjin, Global J. Anal. Chem. 2 (2011) 272-284.

[39] M.F. Perutz, J.V. Kilmartin, K. Nagai, A. Szabo, S.R. Simon, Biochemistry 15 (1976) $378-387$.

[40] P. Ascenzi, A. Bertollini, M. Coletta, A. Desideri, B. Giardina, F. Polizio, R. Santucci, R. Scatena, G. Amiconi, J. Inorg. Biochem. 50 (1993) 263-272.

[41] S.-Y. Park, T. Yokoyama, N. Shibayama, Y. Shiro, J.R.H. Tame, J. Mol. Biol. 360 (2006) 690-701.

[42] E. Di Muzio, D. Toti, F. Polticelli, J. Comput, Aided Mol. Des. 31 (2017) 213-218.

[43] O. Trott, A.J. Olson, J. Comput. Chem. 31 (2010) 455-461.

[44] A. Arnone, M.F. Perutz, Nature 249 (1974) 34-36.

[45] N.M. O’Boyle, M. Banck, C.A. James, C. Morley, T. Vandermeersch, G. R. Hutchison, J. Cheminf. 3 (2011) 33.

[46] G. Morris, R.J. Huey, Comput. Chem. 30 (2009) 2785-2791.

[47] E.F. Pettersen, T.D. Goddard, C.C. Huang, G.S. Couch, D.M. Greenblatt, E.C. Meng, T.E. Ferrin, J. Comput. Chem. 25 (2004) 1605-1612.

[48] N. Shibayama, M. Ohki, J. R. H. Tame, Park S.-Y. J. Biol. Chem. 292 (2017) 18258-18269.

[49] S. Salentin, S. Schreiber, V.J. Haupt, M.F. Adasme, M. Schroeder, Nucl Acids Res. 43 (2015) W443-W447.

[50] R. Grubina, S. Basu, M. Tiso, D.B. Kim-Shapiro, M.T. Gladwin, J. Biol. Chem. 283 (2008) 3628-3638.

[51] F. Azizi, J.E. Kielbasa, A.M. Adeyiga, R.D. Maree, M. Frazier, M. Yakubu, H. Shields, S.B. King, D.B. Kim-Shapiro, Free Rad. Biol. \& Med. 39 (2005) 145-151.

[52] M. Coletta, P. Ascenzi, R. Santucci, A. Bertollini, G. Amiconi, Biochim. Biophys. Acta 1162 (1993) 309-314.

[53] M. Coletta, P. Ascenzi, M. Castagnola, B. Giardina, J. Mol. Biol. 249 (1995) $800-803$.

[54] G. De Sanctis, A.M. Priori, F. Polizio, P. Ascenzi, M. Coletta, J. Biol. Inorg. Chem. 3 (1998) 135-139.

[55] M.F. Perutz, G. Fermi, D.J. Abraham, C. Poyart, E. Bursaux, J. Am. Chem. Soc. 108 (1986) 1064-1078.

[56] N. Shibayama, S. Miura, J.R.H. Tame, T. Yonetani, S.-Y. Park, J. Biol. Chem. 277 (2002) 38791-38796.

[57] P. Reisberg, J.S. Olson, J. Biol. Chem. 256 (1980) 4159-4169.

[58] M. Perrella, N. Davids, L. Rossi-Bernardi, J. Biol. Chem. 267 (1992) 8744-8751. 